\title{
Estudos sobre a ação de leucócitos no endométrio de éguas*
}

\author{
ADRIANA PIRES NEVES
}

\author{
Rodrigo Costa Mattos (Orientador - UFRGS)
}

Banca: Carlos Antonio Mondino Silva (UFSM), Cláudio Alves Pimentel (UFPel), Luis Fernando Fiori Castilho (UPIS - Brasília/DF)

As endometrites bacterianas são uma das principais causas de infertilidade na égua. Entre os tratamentos utilizados nesta patologia, estão as infusões uterinas de plasma homólogo acrescido de leucócitos e a infusão de leucócitos heterólogos criopreservados. O presente trabalho teve por objetivo realizar testes in vivo e in vitro, que foram descritos em dois artigos. No primeiro artigo, objetivou-se avaliar in vitro a quimiotaxia dos leucócitos eqüinos em relação a diferentes quimioatraentes, bem como sua vitalidade e produção de radicais livres de oxigênio (ROS) pós-descongelamento. No experimento 1, testou-se dextrose em concentrações de 0,1, 2 e 6\%, acrescida ou não de interleucina-8 (IL-8), como quimioatraente para leucócitos eqüinos suspensos em salina fosfatada tamponada (PBS) ou em R3F; no experimento 2, testou-se plasma homólogo ou heterólogo, a 3\% (com ou sem IL-8), 10, 30, 60 e 90\%, como quimioatraente; no experimento 3, foi testada a quimiotaxia de leucócitos íntegros em relação a diferentes quantidades de leucócitos lisados. O experimento 4 avaliou a vitalidade e a geração de ROS pelos leucócitos após o descongelamento, comparando quatro graus de diluição em $\mathrm{NaCl}$ e PBS. Concluiu-se que a dextrose não apresenta bom efeito quimioatraente para leucócitos eqüinos. Dentre as concentrações de plasma utilizadas, concentrações de plasma homólogo entre $10 \%$ e $60 \%$ apresentam bom efeito quimiotático. Já o plasma heterólogo apresentou boa atração de leucócitos quando em concentrações de $10 \%$ e de $30 \%$. Na concentração de 10x10\% $/ \mathrm{mL}$, os leucócitos lisados foram capazes de atrair leucócitos em proporção semelhante à da IL-8. Com relação aos testes-pós-descongelamento, células ressuspendidas em $\mathrm{PBS}$ ou $\mathrm{NaCl}$ apresentam vitalidade e geração de radicais livres de oxigênio semelhantes, quando incubados por até 15 minutos. No segundo artigo, realizaram-se testes in vivo compararando cinco tratamentos em éguas, em estro, experimentalmente infectadas com Streptococcus equi subsp. zooepidemicus. Foram utilizadas 25 éguas, 20 consideradas resistentes, e 5 éguas susceptíveis à endometrite. Após 24 horas, os animais foram submetidos a exame clínico, bacteriológico e citológico. Com a presença de quadro clínico de endometrite, as éguas eram submetidas a um dos seguintes tratamentos: 1 - Infusão de 120mL de plasma homológo com de leucócitos frescos; 2 - Infusão de $4 \mathrm{~mL}$ contendo 800 × $10^{6}$ leucócitos íntegros, congelados; 3 - Leucócitos lisados - Infusão de 4 mL contendo 800x10 leucócitos lisados; 4 - IL-8 - Infusão de 4 mL contendo $25 \mathrm{ng} / \mathrm{mL}$ de IL-8 congelada; 5 - Controle - Infusão de 4 mL de meio R3F congelado. Os exames clínico, bacteriológico e citológico foram realizados diariamente até o sétimo dia pós-infecção, ou até a eliminação da bactéria, ou até a ausência de neutrófilos no esfregaço citológico. Após os exames, as éguas receberam o tratamento designado, sendo estes realizados diariamente até a ausência de crescimento bacteriano no exame microbiológico ou por, no máximo, quatro dias. No sétimo dia, todas as éguas foram tratadas com infusão intra-uterina de 5.000.000 UI de penicilina G potássica cristalina. Após o término de um tratamento, aguardava-se cerca de sete dias para a reinfecção, num outro ciclo, quando um outro tratamento era aplicados. Todas as éguas foram submetidas a todos os tratamentos, perfazendo um total de 125 infecções experimentais num delineamento experimental do tipo Quadrado Latino. Não se observaram diferenças significativas no tempo de eliminação bacteriana nas éguas resistentes. Entretanto, nas éguas susceptíveis, observou-se uma cura bacteriana mais rápida quando as éguas foram tratadas com leucócitos frescos, leucócitos congelados e leucócitos lisados, em relação às tratadas com IL-8 e as do grupo controle. Concluiu-se que o efeito bactericida dos leucócitos viáveis ou lisados, associados ou não à presença de fatores de opsonização do plasma, foi o responsável pela cura bacteriológica e que o efeito quimioatraente de neutrófilos, plasma, restos celulares e IL-8 não influiu no tempo de eliminação bacteriana.

Descritores: éguas, endometrite, Streptococcus equi subsp. zooepidemicus, leucócitos, quimiotaxia, congelamento.

Apresentada: 05 fevereiro 2004

"Tese de Doutorado n. 37 (Especialidade: Fisiologia da Reprodução). 114f. Programa de Pós-graduação em Ciências Veterinárias [www.ufrgs.br/ ppgcv] Faculdade de Veterinária, Universidade Federal do Rio Grande do Sul (UFRGS), Porto Alegre/RS. CORRESPONDÊNCIA: A.P. Neves [adripneves@yahoo.com.br; nevesap@vortex.ufrgs.br]. 


\title{
Studies on leukocytes effect on the endometrium of mares ${ }^{* *}$
}

\author{
ADRIANA PIRES NEVES
}

Rodrigo Costa Mattos (Adviser - UFRGS)

\author{
Committee: Carlos Antonio Mondino Silva (UFSM), Cláudio Alves Pimentel (UFPel), Luis Fernando Fiori Castilho (UPIS - Brasília/DF)
}

Bacterial endometritis is one of the major causes of infertility in mares. Uterine infusion of autologous plasma with leukocytes and infusion of frozen heterologous leukocytes are treatments proposed for bacterial endometritis. The present study aimed to do in vivo and in vitro tests, described in two articles. The aim of the first article study was to test, in vitro, chemotaxis of equine leukocytes towards different chemoattractants, as well as its vitality and generation of reactive oxygen species (ROS) post-thawing. Experiment 1 tested chemotactic power of dextrose 0, 1, 2 and 6\%, with and without interleukin-8 (IL-8), to attract equine neutrophils; experiment 2 tested homologous and heterologous plasma in the concentrations 3\% (with and without IL-8), 10,30, 60 and 90\%, as chemoattractant for equine leukocytes; in experiment 3, the chemotaxis of normal equine leucocytes was tested towards different concentrations of lysed leukocytes. Experiment 4 evaluated vitality and generation of reactive oxygen species (ROS) of frozen-thawed equine leukocytes, diluted either in $\mathrm{NaCl}$ or PBS. It was concluded that dextrose doesn't have a good chemotactic effect on equine leukocytes. The homologous plasma concentrations between 10\% and $60 \%$ have a good chemoattractant effect. Heterologous plasma had a good leukocyte attraction when in the concentrations of $10 \%$ and $30 \%$. Lysed leukocytes, at a concentration of $10 \times 10^{6} / \mathrm{mL}$, had a chemotactic effect similar to that of IL-8. The post-thawing tests showed that cells ressuspended in PBS or $\mathrm{NaCl}$ have a similar vitality and $\mathrm{ROS}$, when incubated during 15 minutes. The second article compared, in vivo, five treatments in estrous mares experimentally infected with Streptococcus equi subsp. zooepidemicus. Twenty five mares were used, twenty of them resistant, and five susceptible to endometritis. Cycles were synchronized so that mares were in estrus in the day of infection. Mares were infected with $1 \times 10^{9}$ Streptococcus equi subsp. zooepidemicus in $20 \mathrm{~mL}$ of PBS. Twenty four hours after the inoculation, clinical, bacteriological e cytological examinations were performed. All mares showed clinical signs of endometritis, and were assigned to one of the following treatments: 1 - Fresh leukocytes: Infusion of $120 \mathrm{~mL}$ homologous plasma with leukocytes; 2 - Frozen leukocytes: Infusion of $4 \mathrm{~mL}$ containing 800 x $10^{6}$ frozen leukocytes; 3 - Lysed leukocytes: Infusion of $4 \mathrm{~mL}$ containing $800 \times 10^{6}$ frozen lysed leukocytes; 4 - IL-8 - Infusion of $4 \mathrm{~mL}$ containing $25 \mathrm{ng} / \mathrm{mL}$ of frozen IL-8; 5 - Control - Infusion of $4 \mathrm{~mL}$ containing frozen R3F. Clinical, bacteriological and cytological examinations continued daily until the seventh day after infection, or until bacterial elimination, or until absence of neutrophils in the cytologic smear. After clinical, bacteriological and cytological examinations, mares were treated with the assigned treatment. Treatments were performed daily until no bacterial growth was found or or for no more than four days. On the seventh day, all mares were treated with an uterine infusion of 5.000.000 IU Pennicilin G. After the end of a treatment, there was an interval of seven days until the beginning of the next cycle, when a new treatment was applied.All mares were submitted to all treatments, in a total of 125 experimental infections, in a crossover design with two Latin Squares. No significant difference was found in the time for bacterial elimination in resistant mares. However, in susceptible mares, there was a faster bacterial elimination when mares were treated with fresh, frozen or lysed leukocytes, in comparison to IL-8 and control group. It was concluded that the bactericidal effect of viable or lysed leukocytes, associated or not to plasma opsonizing factors, was responsible for the elimination of bacteria and that the chemotactic effect of neutrophils, plasma, cellular debris and IL-8 did not influence the time needed for the elimination of bacteria.

Key words: mares, endometritis, Streptococcus equi subsp. zooepidemicus, leukocytes, chemotaxis, cryoconservation.

Presented: 04 February 2004

\footnotetext{
**Doctoral Dissertation \#37 (Field: Theriogenology). 114p. Graduate Program in Veterinary Sciences [www.ufrgs.br/ppgcv], Faculdade de Veterinária, Universidade Federal do Rio Grande do Sul (UFRGS), Porto Alegre/Brazil. CORRESPONDENCE: A.P. Neves [adripneves@yahoo.com.br; nevesap@vortex.ufrgs.br].
} 